Article

\title{
2 Optimization of Planting Structure for Irrigation Area with 3 Biannual Cropping Patterns in Xinjiang Oasis in China
}

\author{
4 Bing Liu ${ }^{1}$, Zhenhua Wang ${ }^{1 *}$ \\ ${ }^{1}$ College of Water Resources Engineering, Shihezi University, Shihezi, 832003, China \\ liubing198306@163.com; Tel.: +86-189-9973-0649 \\ * Correspondence: wzh2002027@163.com; Tel.: +86-132-0109-3132
}

Abstract: Light and heat resources are ample in Xinjiang plain oasis region. Planting structure is single in irrigation area, which leads to severe seasonal water shortages due to high concentration of water utilization. Therefore, how to make full use of light and heat resources to develop oasis agriculture without expanding planting scale has become the focus of research. The biannual cropping patterns are possible solutions to the problem. Manas River Irrigation area, which is located on the northern slope of Tianshan Mountain in Xinjiang in China is regarded as a typical case study to analyze the suitable planting structure and planting scale for biannual cropping pattern. The effects of optimizing planting patterns on alleviating the contradiction between water supply and water need, and the efficiency of water resources utilization was also studied. The results of the study show that: (1) the suitable planting scales of Manas River irrigation area in wet year $(\mathrm{P}=25 \%)$, normal year $(\mathrm{P}=50 \%)$, and low flow year $(\mathrm{P}=75 \%)$ are about $72.66 \%, 78.73 \%$ and $83.91 \%$ of the current planting scale. (2) After the planting structure was optimized, the water use process in the irrigation area extends from May to August at present to April to November. The water use ratio at the peak period of water use decreased from 0.847 to 0.601 , and the water use peak was significantly dispersed. (3) Economic benefits per cubic metre of water of the biannual cropping patterns increased from 8.65 yuan $\cdot \mathrm{m}^{-3}$ at present to 9.45 yuan $\cdot \mathrm{m}^{-3}, 10.31$ yuan $\cdot \mathrm{m}^{-3}$ and 11.43 yuan $\cdot \mathrm{m}^{-3}$ in wet year $(\mathrm{P}=25 \%)$, in normal year $(\mathrm{P}=50 \%)$ and low flow year $(\mathrm{P}=75 \%)$ respectively, which proved that replanting crops could improve the efficiency of water resources utilization in irrigated areas. Therefore, the optimal planting pattern can be implemented to improve the utilization efficiency of soil and water resources in irrigation area in the arid oasis with single planting pattern with excessive concentration of water use peak and serious water shortage.

Keywords: optimization of planting structure; biannual cropping pattern; arid oasis irrigation area; moderate scale; benefit

\section{Introduction}

The area of oasis is very limited due to the special natural conditions in arid area[1].Agricultural development is faced with double restrictions of soil and water resource[2]. In order to realize the coordinated development of ecological economy, the efficiency of water and soil resources utilization must be improved in Irrigation area[3-5]. In order to realize the coordinated development of ecological economy, Irrigation area must improve the efficiency of water and soil resources utilization[3-5]. The biannual cropping pattern can improve the utilization efficiency of water and soil resources greatly without increasing the total cultivated land area[6-8].Therefore, it is of positive significance to carry out the optimal allocation of water resources and determine the appropriate scale of water resources according to the law of water consumption in irrigation area for further promoting the process of oasis agricultural modernization[9-11]. The Manas River Irrigation area in Xinjiang (hereinafter referred to as the M.R.I.) was chosen as the research target area. According to the law of 
40 water demand of wheat, corn and oil sunflower, etc, water demand characteristics of Irrigation area under bi41 cropping Model was analyzed based on regional planting structure Adjustment Strategy. And then an optimal model of planting 0structure was established, which aims to the maximization of at comprehensive benefit of agricultural water resources utilization for the irrigation area. The study may provide technical support for intensive and efficient utilization of soil and water resources in the same type of irrigation areas in arid areas.

45

\section{Materials and Methods}

\subsection{Experimental location}

M.R.I. is located in the northern foot of Tianshan Mountain, the southern margin of Junggar Basin, which bordering the Gulban Tungut Desert to the north. The geographical coordinates are mainly between latitude 43 ${ }^{\circ} 26^{\prime}$ to $45^{\circ} 11$ ' $\mathrm{N}$ and longitude $85^{\circ} 03^{\prime}-86^{\circ} 42^{\prime} \mathrm{E}$. The altitude of irrigation area is between $380 \mathrm{~m}$ and $420 \mathrm{~m}$. The sunshine time is about 3000 hours, and the frost-free period is about 180 days. It's suitable for growing crops such as cotton, wheat, corn, oil sunflower and grapes[13]. Total area is about $143.65^{*} 10^{3} \mathrm{hm}^{2}$. The schematic of the irrigation area is shown in Figure 1.

The M.R.I. is mainly supplied by four reservoirs, namely, the mushroom lake reservoir, the Daquanggou reservoir, the Jiahezi reservoir, the Yuejin reservoir and the Keneswatt reservoir. The main technical parameters of the four reservoirs were showed in Table 1 [13].

The main channels of M.R.I. include Shihezi main canal and Tongzi canal C1, Daquangou flood diversion canal two storeys connected to canal C2, Liufu canal C3, west diversion canal and flood diversion channel C4, Jiahezi west drainage canal C5, leaping into drain C6, mushroom drain C7, West bank canals C8, Mosuo Bay main Nullah C9, Jiahezi Flood Spillway C10 and East Coast Grand Canal C11.

Table 1. Characteristic parameters of reservoirs

\begin{tabular}{|c|c|c|}
\hline reservoirs & total reservoir capacity $\left(10^{8} \mathrm{~m}^{3}\right)$ & dead storage $\left(10^{4} \mathrm{~m}^{3}\right)$ \\
\hline Moguhu reservoir & 1.80 & 750 \\
\hline Daquangou reservoir & 0.40 & 500 \\
\hline Jiahezi reservoir & 1.01 & 3500 \\
\hline Yuejin reservoir & 1.10 & 2000 \\
\hline Kenswatt reservoir & 1.88 & 6200 \\
\hline
\end{tabular}




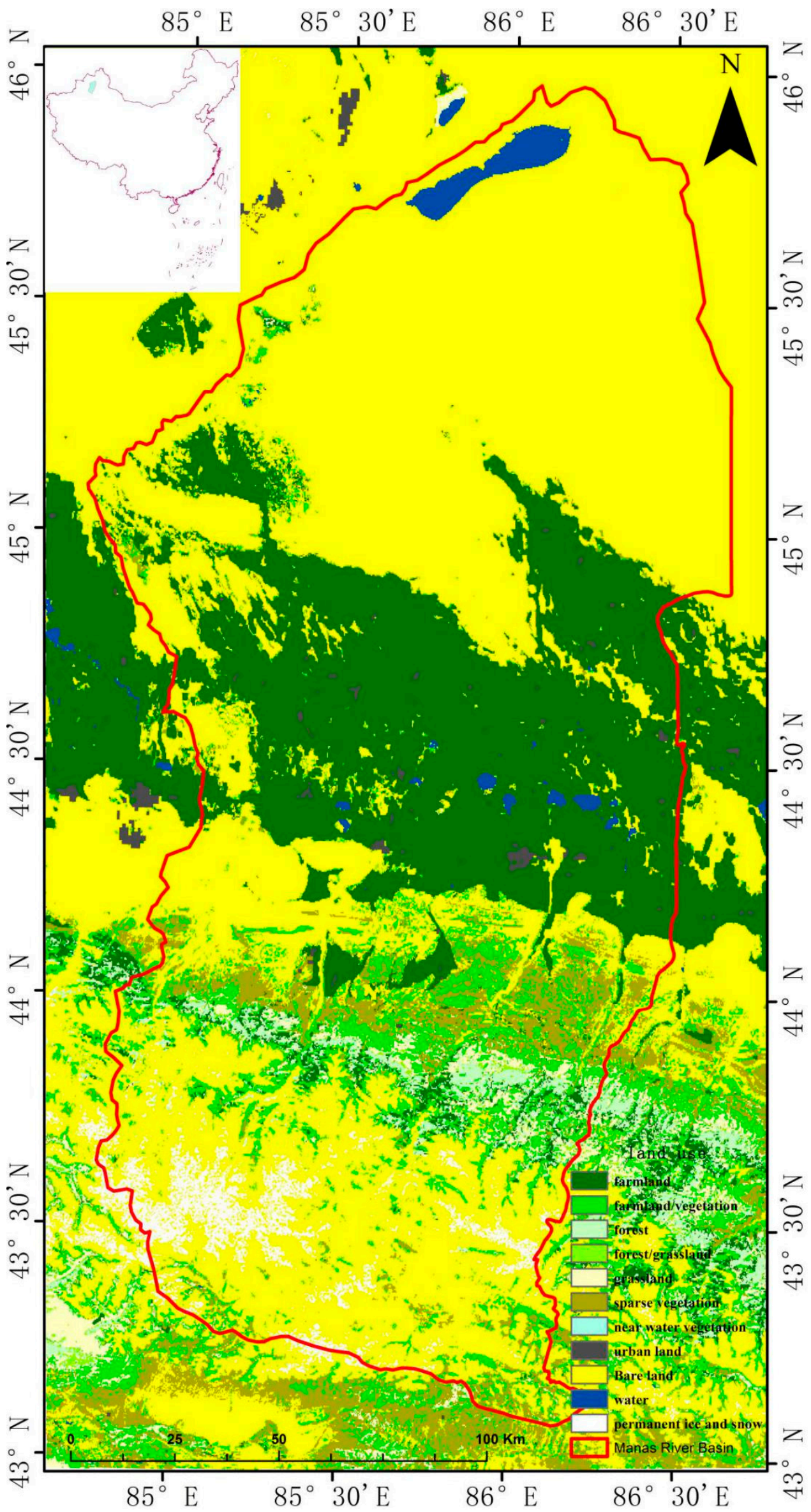

Figure 1. Location of irrigation area 


\subsection{Datas and Methods}

The data to be collected include hydrological data, agricultural statistics of irrigated areas, meteorological, water conservancy, land and other relevant departments through participatory surveys, collecting crop types, planting areas, etc. Basic data of water demand and yield during crop growth period. Based on the statistical data, the characteristics of planting structure in each region are analyzed on the basis of numerical statistics, and the characteristics of water use are studied, and then according to the time series of crop growth, the planting structure and water use characteristics on the time axis of each region were studied[13-14].

The optimization of crop planting structure in irrigated area is mainly to consider the effect of water peak dispersion of replanted crops, and to stagger the water use peak of each irrigation area by collocating a certain amount of replanted crops[13]. In order to alleviate the situation of seasonal water shortage during the period of cotton water demand in various irrigation areas, and at the same time, to find alternative cash crops with small water demand and high economic output value to replace cotton, and to reduce the proportion of cotton planting, The maximum peak value of water use in irrigation period was further reduced, and various crops were rotated in order to avoid the degradation of farmland and the decrease of output value caused by long-term continuous cropping.

The optimization of water distribution in reservoir group and planting area in M.R.I. is mainly through the establishment of water model for irrigation area, and the overall optimization of irrigation area mainly includes two aspects, one is the optimization of crop planting structure in irrigation area, the other is the optimization of crop planting structure in irrigation area. The second is the water distribution of reservoir group and the optimization of planting area in each sub-irrigation area. The two aspects of optimization are not isolated from each other, but are adjusted by program [13-17]. First, according to the water coming from the Manas River, the initial storage capacity of the reservoir is obtained. The amount of groundwater and other amount of water that can be used in Irrigation area are exploited annually. The reasonable proportion of crop planting in irrigation area is determined by the objective function of the whole income of agriculture in irrigation area, and then according to the irrigation of various crops. System and acreage calculation for each period of time (the program takes ten days as the basic time dispatching unit), the water demand of each irrigation area. Finally, according to the water demand of the irrigation area, the water transport capacity of each key channel and the corresponding capacity of each reservoir at the end of every ten days are determined. Finally, with the objective function of maximizing the income of the irrigation area, the planting scale and the optimal planting structure and planting scale are determined.

\subsection{Establishment of optimization model for planting structure for irrigation area}

\subsubsection{Main optimization of crop determination in irrigation area}

At present, the common crops in Mahe Irrigation area are wheat (winter wheat and spring wheat, rice, summer corn, silage corn, watermelon, oil sunflower, tomato, grape (wine grape and fresh grapevine, pepper, cotton, alfalfa). Among them, winter wheat, spring wheat, rice and summer corn are food crops, oil sunflower as oil crops, tomatoes, grapes, pepper, cotton, watermelon as cash crops, silage corn and alfalfa as main forage crops, Green manure is mainly used to improve soil. Rice in grain crops has higher water consumption, lower net income, lower planting area, and lower yield and harvest of spring wheat than winter wheat. Although the income of watermelon is high, the water consumption is very high, the price is unstable, and the requirement of farmland land is more strict, only some areas in the lower field are planted in a small amount at present. None of the three crops were considered for optimization.

\subsubsection{Crop selection for possible replanting}

In recent years, irrigation of cotton cropping resulted in land degradation, cotton production has been quite common phenomenon. In order to change this situation, and considering the Shihezi area of food security, introduction of winter wheat and cotton rotation, at the same time to solve only wheat low income and idle land after July,August and September, the full use of the accumulated temperature can not be used efficiently, summer maize silage maize, oil sunflower, green manure and wheat cropping, these oversowing combinations 
110 have been proved feasible. The local agricultural production of cotton cropping pattern set for cotton-cotton-

111 wheat + maize (or corn silage, sunflower oil, green manure).

112 At present, under the meteorological conditions of irrigation area, the cash crops that may replace cotton 113 mainly include grape and pigmented pepper. The benefit of grape is higher, but the labor cost and technical 114 requirement are higher, the risk is also higher, and the profit of pigment pepper is slightly lower. But the water 115 consumption is also low, it can be mechanized sowing and harvesting, the risk is lower, so the cash crop instead 116 of cotton is mainly pigmenpigment pepper.

117 2.3.3 Construction of optimal allocation Model of planting structure in Irrigation area

\section{Object function}

119 The objective function of the model is to maximize the expected total agricultural income (I) of Irrigation 120 area.[17-19]

$$
\mathrm{I}=S(i) * \sum_{j=1}^{m} g(i, j) * P(i, j)
$$

122 Where:

123 I $\_$Expected overall Agricultural income in irrigation area.

124 S(i) _ Planting area in area $i$.

$\eta(\mathrm{i})$ W Water utilization coefficient of canal system below main canal. 


$$
c \min (k) \geq x(12, k) *(1-o(12, k))+x(13, k) *(1-o(13, k))
$$

(2) $G(\mathrm{i}, k) \ldots$ Water supply constraint in Irrigation area i:

$$
G(\mathrm{i}, k) \geq X(\mathrm{i}, k)
$$

(3) $x(i, k) \_$Overwater capacity constraint of Channel :

$$
x(i, k) \leq x \max (i, k)
$$

(4) $V(i, k) \_$Reservoir storage capacity constraint:

$$
V \min (i, k) \leq V(i, k) \leq V \max (i, k)
$$

(5) Non-negative constraints:The actual quantities in the model must not be less than 0.

\subsubsection{Initial data determination}

Determination of minimum planting proportion of main crops

The minimum planting area of grain crops is mainly restricted by regional food security. According to the regional statistical data from 1996 to 2016, the main types of grain crops are corn and wheat[20]. And 53\% is corn, while $47.47 \%$ is wheat, which were calculated according to the average yield per unit area. The lower limit of wheat planting area is $17.82 * 10^{3} \mathrm{hm}^{2}, 18.00^{*} 10^{3} \mathrm{hm}^{2}$ for wheat and $16.75^{*} 10^{3} \mathrm{hm}^{2}$ for summer corn.

According to the estimate of the China Cotton Institute, 6.4 million tons of cotton will be produced domestically. According to the regional agricultural plan, the minimum planting area of cotton is $61.6^{*} 10^{3} \mathrm{hm}^{2}$, which can be used as coarse feed for both wheat and corn stalks. And the irrigated area has been planned to be $1.71 * 10^{3} \mathrm{hm}^{2}$ for reseeding winter wheat and $1.67 * 10^{3} \mathrm{hm}^{2}$ for resowing summer corn, so there is no need to plant silage corn in the area. But considering that the planting area of winter wheat is still $1.60^{*} 10^{3} \mathrm{hm}^{2}$, And the economic benefit of wheat and summer corn straw is slightly poor, so the planting area of winter wheat silage corn is $0.47 * 10^{3} \mathrm{hm}^{2}$, and the remaining $0.47^{*} 10^{3} \mathrm{hm}^{2}$ of silage corn is planned. It is replanted as green manure for winter wheat.

According to regional animal husbandry development needs, The lower limit of planting area for alfalfa is $9.07 * 10^{3} \mathrm{hm}^{2}$.

Because winter wheat is replanted with summer corn, winter wheat with oil sunflower, winter wheat with silage corn and winter wheat with green manure, the peak water requirement of winter wheat is relatively dispersed, so it can be adjusted properly for winter wheat to sow oil sunflower and winter wheat to sow summer corn again in irrigated area. The planting proportion of winter wheat silage corn and winter wheat green manure was replanted[20-23]. The minimum planting area of main crops in irrigated area was as shown in Table 2 after comprehensive adjustment. 
168

Table 2. Minimum planting proportion of each crop in irrigation area

\begin{tabular}{cccccc}
\hline crop & WO. & WS. & Cot. & WSc. & WG. \\
\hline $\begin{array}{c}\text { Planting } \\
\text { proportion }\end{array}$ & 0.7 & 0.9 & 21.9 & 15.4 & 11.9 \\
\hline
\end{tabular}

169 Note:There are no minimum planting proportion for other crops. There are different crops irrigation schemes

170 as WO (Winter wheat + oil sunflower), WS (Winter wheat+summer maize), Cotton (Cot.), WSc(Winter wheat

171 +silage corn) and WG(Winter wheat + green manure).

172 Crop irrigation system

173 The irrigation system for each crop (replanted crop combination) is shown in Table 3.[12]

174

175

Table 3. Irrigation schedule of different crops (unit: $\mathrm{m}^{3} / \mathrm{hm}^{2}$ )

\begin{tabular}{|c|c|c|c|c|c|c|c|c|c|c|c|}
\hline & Crops & $W O$. & $W S$ & Cot. & Tom. & $\mathrm{P} p$ & Clv. & Fl. & WSc. & WG. & Gra. \\
\hline \multicolumn{12}{|l|}{ Time } \\
\hline & Crop & (1 & (2 & \multirow{2}{*}{ (3) } & \multirow{2}{*}{ (4) } & ( 5 & ( 6 & (7 & ( 8 & (9 & \multirow{2}{*}{ (10) } \\
\hline & number & ) & ) & & & ) & ) & ) & ) & ) & \\
\hline \multirow{2}{*}{ Apr. } & $\begin{array}{l}\text { Middle } \\
\text { ten-day }\end{array}$ & 450 & 450 & 0 & 0 & 0 & 0 & 0 & 450 & 450 & 0 \\
\hline & $\begin{array}{c}\text { Last ten- } \\
\text { day }\end{array}$ & 375 & 375 & 225 & 0 & 0 & 0 & 0 & 375 & 375 & 450 \\
\hline \multirow{3}{*}{ May } & $\begin{array}{c}\text { Fist ten- } \\
\text { day }\end{array}$ & 375 & 375 & 0 & 0 & 0 & 375 & 0 & 375 & 375 & 0 \\
\hline & $\begin{array}{l}\text { Middle } \\
\text { ten-day }\end{array}$ & 900 & 900 & 0 & 0 & 0 & 375 & 825 & 900 & 900 & 0 \\
\hline & $\begin{array}{c}\text { Last ten- } \\
\text { day }\end{array}$ & 525 & 525 & 225 & 0 & 0 & 375 & 0 & 525 & 525 & 375 \\
\hline \multirow{3}{*}{ Jun. } & $\begin{array}{c}\text { Fist ten- } \\
\text { day }\end{array}$ & 975 & 975 & 0 & 0 & 450 & 375 & 375 & 975 & 975 & 0 \\
\hline & $\begin{array}{l}\text { Middle } \\
\text { ten-day }\end{array}$ & 0 & 0 & 450 & 375 & 450 & 375 & 450 & 0 & 0 & 375 \\
\hline & $\begin{array}{c}\text { Last ten- } \\
\text { day }\end{array}$ & 0 & 0 & 225 & 300 & 450 & 375 & 0 & 0 & 0 & 0 \\
\hline July & $\begin{array}{c}\text { Fist ten- } \\
\text { day }\end{array}$ & 225 & 225 & 450 & 375 & 300 & 375 & 0 & 0 & 0 & 0 \\
\hline
\end{tabular}




\begin{tabular}{|c|c|c|c|c|c|c|c|c|c|c|c|}
\hline & $\begin{array}{l}\text { Middle } \\
\text { ten-day }\end{array}$ & 0 & 450 & 450 & 300 & 300 & 375 & 375 & 0 & 0 & 450 \\
\hline & $\begin{array}{c}\text { Last ten- } \\
\text { day }\end{array}$ & 0 & 450 & 450 & 375 & 300 & 0 & 450 & 375 & 300 & 450 \\
\hline \multirow{3}{*}{ Aug. } & $\begin{array}{c}\text { Fist ten- } \\
\text { day }\end{array}$ & 300 & 300 & 450 & 300 & 600 & 0 & 0 & 375 & 300 & 0 \\
\hline & $\begin{array}{l}\text { Middle } \\
\text { ten-day }\end{array}$ & 375 & 300 & 450 & 375 & 300 & 375 & 825 & 375 & 300 & 375 \\
\hline & $\begin{array}{c}\text { Last ten- } \\
\text { day }\end{array}$ & 375 & 300 & 225 & 300 & 0 & 375 & 0 & 375 & 300 & 300 \\
\hline \multirow{3}{*}{ Sep. } & $\begin{array}{c}\text { Fist ten- } \\
\text { day }\end{array}$ & 375 & 300 & 0 & 375 & 0 & 0 & 0 & 375 & 300 & 0 \\
\hline & $\begin{array}{l}\text { Middle } \\
\text { ten-day }\end{array}$ & 375 & 0 & 0 & 0 & 0 & 0 & 0 & 375 & 300 & 0 \\
\hline & $\begin{array}{c}\text { Last ten- } \\
\text { day }\end{array}$ & 375 & 0 & 0 & 0 & 0 & 225 & 0 & 375 & 0 & 0 \\
\hline \multirow{3}{*}{ Oct. } & $\begin{array}{c}\text { Fist ten- } \\
\text { day }\end{array}$ & 0 & 0 & 0 & 0 & 0 & 225 & 0 & 375 & 0 & 0 \\
\hline & $\begin{array}{l}\text { Middle } \\
\text { ten-day }\end{array}$ & 0 & 0 & 0 & 0 & 0 & 225 & 450 & 0 & 0 & 900 \\
\hline & $\begin{array}{l}\text { Last ten- } \\
\text { day }\end{array}$ & 450 & 450 & 0 & 0 & 0 & 225 & 450 & 450 & 450 & 0 \\
\hline Nov. & $\begin{array}{c}\text { Fist ten- } \\
\text { day }\end{array}$ & 375 & 375 & 0 & 0 & 0 & 0 & 0 & 375 & 25 & 0 \\
\hline
\end{tabular}

Note:There is no water requirement of each crop in other periods. There are different crops irrigation schemes as WO (Winter wheat+oil sunflower), WS (Winter wheat+summer maize), Cot.(Cotton), Tom.(Tomato), Pp (Pigment pepper),Cl.(Clove), Fl.(Forest land), WSc(Winter wheat + silage corn), WG(Winter wheat + green manure) and Gra.(Grape).

\section{Results and discussion}

\subsection{Analysis on appropriate scale of Irrigation area}

The suitable planting scales of irrigation area under water frequency $\mathrm{P}=25 \%, 50 \%$ and $75 \%$ are showed in Figure 2. 


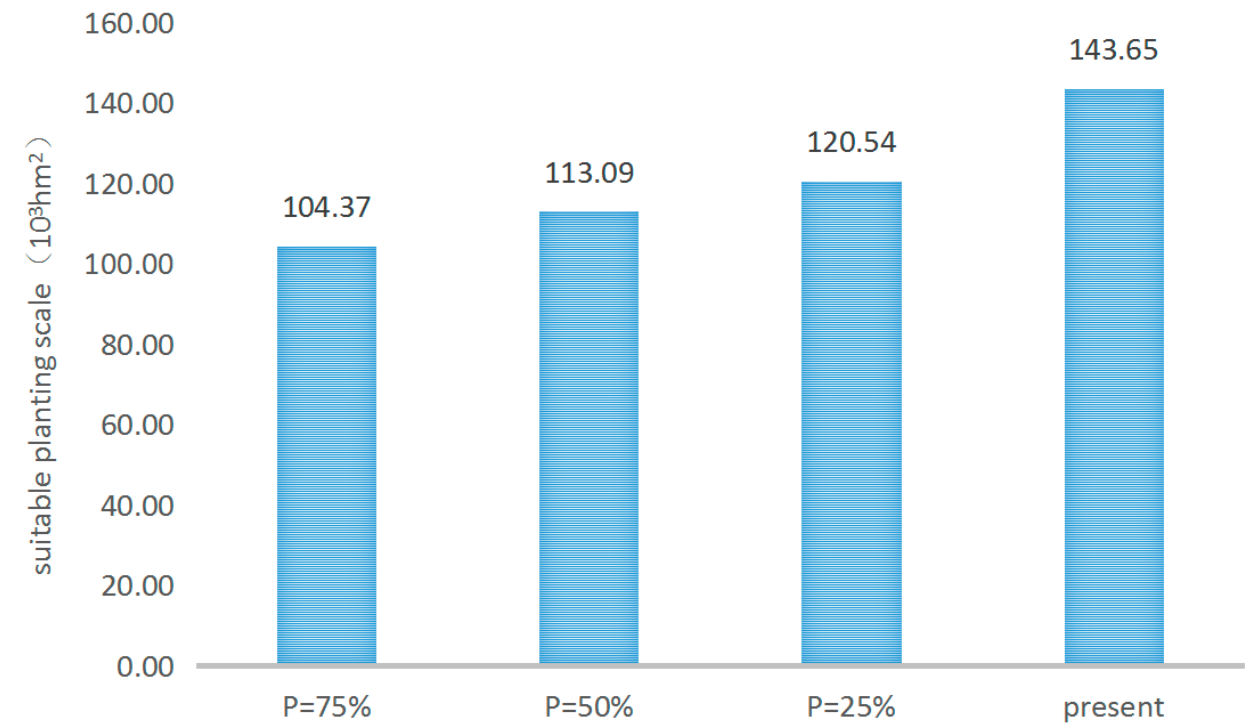

Figure 2. Comparison of suitable planting scale in irrigation areas of different levels

The suitable planting areas of the irrigation area of different levels are $104.37 * 10^{3} \mathrm{hm}^{2}, 113.09 * 10^{3} \mathrm{hm}^{2}$ and $120.54 * 10^{3} \mathrm{hm}^{2}$, which are about $72.66 \%, 78.73 \%$ and $83.91 \%$ of the present planting scale respectively, which indicate that the irrigation area of Mahe irrigation area is in the state of water shortage on the whole. The results show that the soil and water resources in the irrigated area are unbalanced and the cultivated land in the irrigated area can not be fully utilized[24-26]. At the same time, it also reveals the root cause of the overexploited groundwater to maintain the current cultivated land scale under the condition of Irrigation area.

\subsection{Optimization of crop planting proportionn Irrigation area}

According to the model solution, the optimal planting ratio of irrigation area was calculated as shown in Table 4.

Table 4. Optimization of crop planting structure in Irrigation area of different levels

\begin{tabular}{cccccccccccc}
\hline Crops & WO. & WS. & Cot. & Tom. & Pp. & Clv. & Fl. & WSc. & WG. & Gra. \\
\hline $\mathrm{P}=25 \%$ & 0.002 & 0.106 & 0.487 & 0.000 & 0.267 & 0.051 & 0.080 & 0.002 & 0.002 & 0.003 \\
$\mathrm{P}=50 \%$ & 0.002 & 0.106 & 0.468 & 0.000 & 0.288 & 0.051 & 0.080 & 0.002 & 0.002 & 0.001 \\
$\mathrm{P}=75 \%$ & 0.007 & 0.154 & 0.219 & 0.000 & 0.062 & 0.110 & 0.080 & 0.009 & 0.009 & 0.300 \\
\hline
\end{tabular}

Table 4 shows that cotton has the largest proportion in the current planting pattern, has decreased significantly from above 0.750 in the three level years. Even in wet year $(\mathrm{P}=25 \%)$, the proportion of cotton planting decreased to 0.487 . The planting proportion of other non-traditional dominant crops, such as grape and alfalfa, increased obviously in the dry water year. It is worth paying attention to that the planting proportion of pigment pepper is also closely related to the variation of abundance and withered in incoming water, from 0.267 in high water year to 0.062 in dry year. Other multiple cropping combinations such as winter wheat and oil sunflower, winter wheat and summer corn, winter small The ratio of wheat and green manure was increased from 0.002 to more than 0.007 in high water year and normal water year, which indicated that increasing the proportion of replanted crops was beneficial to the comprehensive utilization of water resources in irrigated area[27]. 
In general, pigment pepper was adjusted to the maximum or close to the maximum in the range of planting proportion adjustment. In some periods, the proportion of wine grape planted in irrigated areas increased slightly in order to alleviate the water shortage of pigmented pepper. The proportion of other crops planted is the smallest. This is because compared with other crops, pigmented pepper has higher income, lower water consumption, and the highest water output value. Wine grape has lower water demand and higher income during the water demand period of pigmented pepper, which was selected by the procedure as peak-shaving crop. However, the grape yield is not normal annual income, and the price of tomato is determined by excessive consideration of risk in determining the price of tomato. However, the price of the product fluctuates all the time, the crop yield is not fixed, and the distortion of the data is inevitable. The result of adjusting the proportion of crop planting in different irrigation areas also reflected the trend that pigment pepper could replace cotton as the main cash crop to some extent[28].

\subsection{Effect of multiple cropping combination on the peak of water demand}

According to the amount of irrigation needed in each period of irrigation period in each level year, the proportion of water demand in each period of irrigation period to the total amount of irrigation required in each period of the year was calculated as shown in Figure 3.

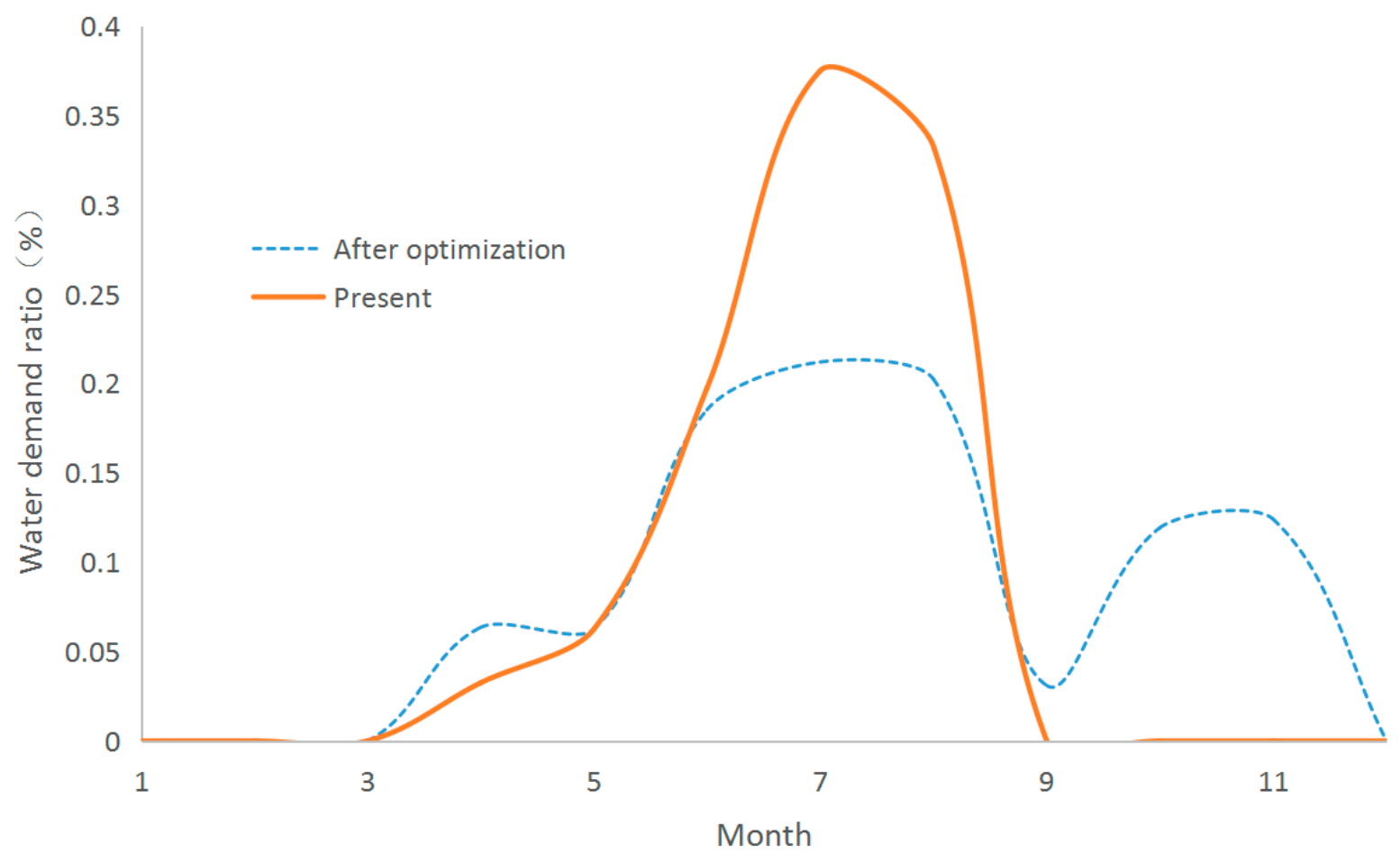

Figure 3. Comparison of water use process before and after optimization

After the optimization of planting structure, the process of water demand in Irrigation area was significantly reduced from May to August of present situation of water use process to April to November, and the proportion of water used in peak period of water use was significantly dispersed from 0.847 to 0.601 . The increase of water demand in the later stage was mainly due to the need for winter irrigation of winter wheat. Therefore, compared with one crop a year, The peak of water use was significantly reduced, and the process of water use was obviously extended. It is helpful to alleviate water supply pressure during peak periods of water use in irrigation area.

\subsection{Analysis on Water-saving effect of multiple cropping combination}

Under the same planting area of grain, oil and fodder crops, the total annual water consumption of the main crops such as winter wheat, spring corn, summer corn and oil sunflower was calculated under the same planting 
234 area in $\mathrm{P}=75 \%$. The annual water consumption is showed in Table 5 . And the total water consumption of oil 235 and feed crops is showed in Table 6.

Table 5. Total water consumption of grain, oil and fodder crops under replanting mode

\begin{tabular}{cccc}
\hline Multiple cropping combination & plant area & irrigation norm & water consumption ( \\
$\left(10^{3} \mathrm{hm}^{2}\right)$ & $\left(\mathrm{m}^{3} / \mathrm{hm}^{2}\right)$ & $\left.10^{4} \mathrm{~m}^{3}\right)$ \\
\hline Winter wheat + Oil sunflower & 7.07 & 6825 & 6823 \\
Winter wheat + summer corn & 10 & 6750 & 717.75 \\
Winter wheat + silage corn & 0.97 & 7425 & 12290.75 \\
Total water consumption & & & 6750 \\
\hline
\end{tabular}

Table 6. Total annual water consumption of grain, oil and fodder crops per year at present

\begin{tabular}{cccc} 
crops & plant area & irrigation norm & water consumption ( \\
& $\left(10^{3} \mathrm{hm}^{2}\right)$ & $\left(\mathrm{m}^{3} / \mathrm{hm}^{2}\right)$ & $\left.10^{4} \mathrm{~m}^{3}\right)$ \\
\hline Winter wheat & 18.04 & 4425 & 7979.75 \\
Helianthus annuus & 7.07 & 4500 & 3180 \\
summer corn & 10 & 4200 & 4200 \\
silage corn & 0.97 & 3750 & 362.5 \\
Total water consumption & & & 15722.25 \\
\hline
\end{tabular}

Table 5 shows that the total annual water consumption of grain, oil and fodder crops is $12290.75^{*} 10^{4} \mathrm{~m}^{3}$. While the water consumption of green manure is not included in the way of replanting. However, table 6 shows that when the same crop area is planted, the grain are produced once a year under the same cropping area, the total annual water consumption of fodder crops is $15722.25^{*} 10^{4} \mathrm{~m}^{3}$, which is $21.83 \%$ lower than the annual water consumption of replanting the crops once a year. When the total planting area is the same, it can be seen that the annual water consumption of fodder crops is lower than that of once a year. Multiple cropping combination crops can save water to some extent, but the total cultivated land area used by replanting crops is only $50 \%$ of the current planting pattern. Therefore, when the total tillage area is the same, the total water consumption of the replanting pattern is 1.56 times of the current water consumption. 
12

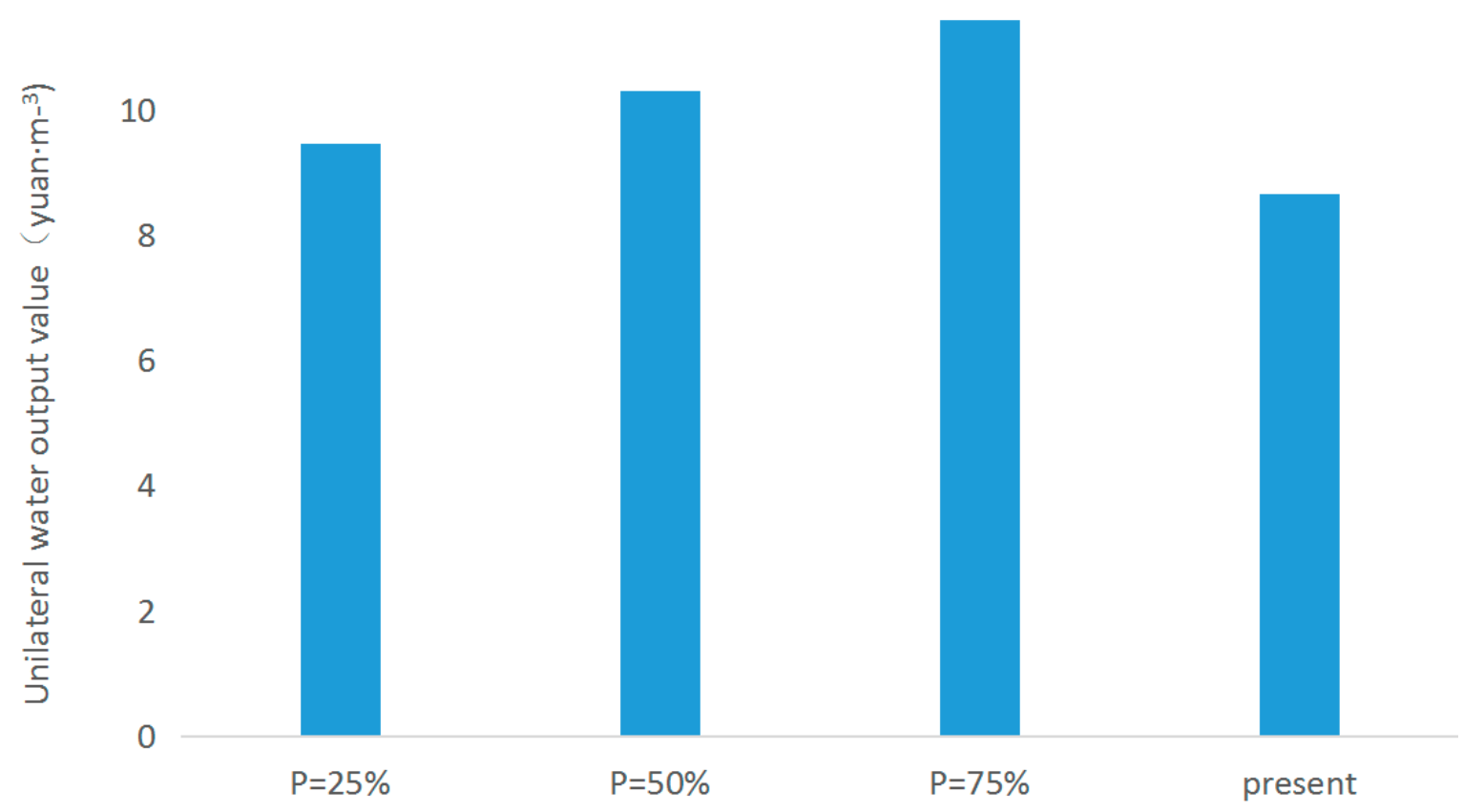

Figure 4. Unilateral water output value

Figure 4 shows that the benefit of unilateral water in three level years were improved in varying degrees. Economic benefits per cubic metre of water of the biannual cropping patterns increased from $8.65 \mathrm{yuan} \cdot \mathrm{m}^{-3}$ at present to 9.45 yuan $\cdot \mathrm{m}^{-3}, 10.31$ yuan $\cdot \mathrm{m}^{-3}$ and 11.43 yuan $\cdot \mathrm{m}^{-3}$ in wet year $(\mathrm{p}=25 \%)$, normal year $(\mathrm{p}=50 \%)$ and low flow year $(\mathrm{p}=75 \%)$ respectively, which proved that replanting crops could improve the efficiency of water resources utilization in irrigated areas, which proved that replanting crops could improve the efficiency of water resources utilization in irrigation areas, and the value of unilateral aquatic products would be higher when the water came to dry up. The results are different from [28,29]. This may be due to different agricultural market prices and regional differences in yields under light and heat conditions. When the water supply is dry, the process of water supply is mainly guided by crops with better economic benefit, but weakened by the capacity of overcurrent of canal system, which improves the efficiency of water supply to a certain extent[29].

\section{Conclusions}

On the basis of synthetically considering all aspects of water use in irrigation area, the minimum demand of crops in irrigation area was guaranteed, and the planting structure, planting area and water distribution process of reservoir group in irrigation area were optimized. The reasonable planting area, the reasonable planting proportion of each crop and the reasonable water distribution process of the corresponding reservoir group and backbone canal in the irrigation area with frequency of incoming water are obtained.

(1) In three level years $(\mathrm{P}=25 \%, 50 \%$ and $75 \%)$, the suitable planting areas are $104.37 * 10^{3} \mathrm{hm}^{2}$, $113.09 * 10^{3} \mathrm{hm}^{2}$, which are about $72.66 \%, 78.73 \%$ and $83.91 \%$ of the present planting scale respectively. It reveals that the soil and water is in an unbalanced state under the current planting scale.

(2) The optimal planting structure and irrigation water is the most intense month respectively in mid June, 6 months late and mid August and late October and mid August to early November, compared with the present planting mode, peak water was dispersed. Crop water requirement has combined over sowing peak the effect can be better dispersed water peak.

(3) Compared to planting pattern crops, crop sowing combinations can reduce the complex irrigation area of grain, oil, feed crops and planting proportion, planting area decreased to about $50 \%$ of the present value is higher, the unilateral fisheries, different years increased by $9.24 \%$ to $32.14 \%$ compared to the status quo. And water-saving effect is not obvious. so the promotion of two a year of planting in a reasonable cut cultivated land under the condition that the scale of increase of winter wheat farmland and reduce the annual income of 
grain, oil, feed crops and planting proportion to realize the coordinated development of ecology and economy in arid oasis area.

Acknowledgments: This study was supported by the National Key R\&D Program of China (2017YFC0404304, 2016YFC0403101). The National Natural Science Foundation of China (51469028).

Author Contributions: All authors contributed extensively to the work presented in this paper. Bing Liu collected data, designed and performed research, wrote, Zhenhua Wang revised and approved the fnal manuscript.

Conflicts of Interest: The authors declare no conflict of interest. The founding sponsors had no role in the design of the study; in the collection, analyses, or interpretation of data; in the writing of the manuscript, and in the decision to publish the results.

\section{References}

1. Abdalla O, Chen M. Special issue on water resources in arid areas. Arabian Journal of Geosciences, 2017, 10(1):6.

2. Li Y, Yang X G, Wang W F, et al. Changes of China agricultural climate resources under the background of climate change. I. Spatiotemporal change characteristics of agricultural climate resources in South China.Chinese Journal of Applied Ecology, 2011, 21(10):2605-2614.

3. Wong H S, Sun N Z, Yeh W W G. Optimization of Conjunctive Use of Surface Water and Groundwater with Water Quality Constraints. International Review of Hydrobiology, 2014, 97(97):526-541.

4. Wang Z H, Liao R K, Lin H, et al. Effects of drip irrigation levels on soil water,salinity and wheat growth in North China. Int J Agric \& Biol Eng, 2018, 11(1): 146-156.

5. Trentacoste E R, Connor D J, Gómez-Del-CampoM. Row orientation: Applications to productivity and design of hedgerows in horticultural and olive orchards. Scientia Horticulturae, 2015, (187) :15-29.

6. Xiao Y, Mignolet C, Mari J F, et al. Modeling the spatial distribution of crop sequences at a large regional scale using land-cover survey data: A case from France. Computers \& Electronics in Agriculture, 2015, 102(102):51-63.

7. Plourde J D, Pijanowski B C, Pekin B K. Evidence for increased monoculture cropping in the Central United States. Agriculture Ecosystems \& Environment, 2013, 165(1751):50-59.

8. Berger M, Finkbeiner M. Water footprinting: how to address water use in life cycle assessment?. Sustainability, 2010, 2(4):919-944.

9. Sun Zhi-lin, Xia Shan-shan, Xu Dan, et al.Optimum allocation model of regional water resources. Journal of Zhejiang University (Engineering edition), 2009: 344-348.

10. Tovihoudji P G, Akponikpè P B I, Adjogboto A, et al. Combining hill-placed manure and mineral fertilizer enhances maize productivity and profitability in northern Benin. Nutrient Cycling in Agroecosystems, 2017:1-19.

11. Environmental impact report of Manas River Basin Planning, Xinjiang production and Construction Corps Survey and Design Institute. 1995.

12. Xinjiang Production and Construction Corps Statistics Department.Xinjiang Production and Construction Corps Statistics. Department Statistical Yearbook. Beijing: China Statistical Publishing House, 1996 2016.

13. Research Institute of survey planning and design of Xinjiang production and Construction Corps. The eight division of Xinjiang production and Construction Corps, Shihezi water saving planning report. 2013.

14. Xinjiang production and Construction Corps Prospecting Planning and Design Research Institute. Report on Water Resources argumentation of Manas River Keneswatt Water Conservancy Project in Xinjiang. 2017.

15. Xie Xinmin, Chen Shouyu, Wang Bende, et al.Model of fuzzy optimal operation of hydropower station reservoir group and objective coordination-fuzzy programming method. Advances in Water Science, 1995 (6):32-39.

16. Manas River Basin Irrigation area Management Committee. Manas River Basin Management regulations 1996. 
323
17. Wong H S, Sun N Z, Yeh W W G. Optimization of Conjunctive Use of Surface Water and Groundwater with Water Quality Constraints. International Review of Hydrobiology, 2014, (97):526-541.

18. Yang K, Liu Y B. System decomposition-coordination macro-decision method for reservoirs based on multi-objective analysis. Advances in Water Science, 2001.

19. Mohan S, Raipure D M. Multiobjective Analysis of Multireservoir System. Journal of Water Resources Planning \& Management, 1992, 118(4):356-370.

20. Ha11.W. A. Butcher, A.Esogbue. Optimization of a multiple purpose reservoirby dynamic programming. Resources Research, 1968 (4): 471-486.

21. Feng Shangyou. Methodology and application of multi-objective decision making. Huazhong University of Technology Press, 1990.

22. Silver Mugisha ,Sanford V. Berg,Sustain.Adaptive leadership in water utility operations: the case of Uganda. Water Resour. Manag. 2017, 3:171-179.

23. Schilling K E, Then S R, Ikenberry C D. Water Balance Modeling of Temporary Ponding in a Drained Prairie Pothole Wetland. Environmental Modeling \& Assessment, 2018:1-12.

24. Gerhard Langenberger. Georg Cadisch . Konrad Martin. Shi Min. Hermann WaibelRubber intercropping: aviable concept for the 21st century?. Agroforest Syst, 2017, 91:577-596.

25. Edwin NuijtenJan de WitLeen Janmaat,et al. Understanding obstacles and opportunities for successful market introduction of crop varieties with resistance against major diseases. Org.Agr, 2017(9):165-192.

26. Peters V E. The value of fruit security for the conservation of a neotropical frugivore in human-dominated landscapes. Biodiversity \& Conservation, 2011, 20(9):2041-2055.

27. Orton R W, Mcelroy E J, Mcbrayer L D. Predation and cryptic coloration in a managed landscape. Evolutionary Ecology, 2018:1-17.

28. Service U S F. National Forest System Land Management Planning. Federal Register, 2012(251):80299.

29. Andriamparany J N, Brinkmann K, Wiehle M, et al. Modelling the distribution of four Dioscorea, species on the Mahafaly Plateau of south-western Madagascar using biotic and abiotic variables. Agriculture Ecosystems \& Environment, 2015, 212:38-48. 